\title{
Teaching NeuroImages: Intracranial extramedullary hematopoiesis
}

\section{Blood disorders on the mind}

Lily W. Zhou, MD, and Tychicus Chen, MD, FRCPC

Neurology ${ }^{\circledR}$ 2020;95:e606-e607. doi:10.1212/WNL.0000000000009926

Figure Extramedullary hematopoiesis on MRI

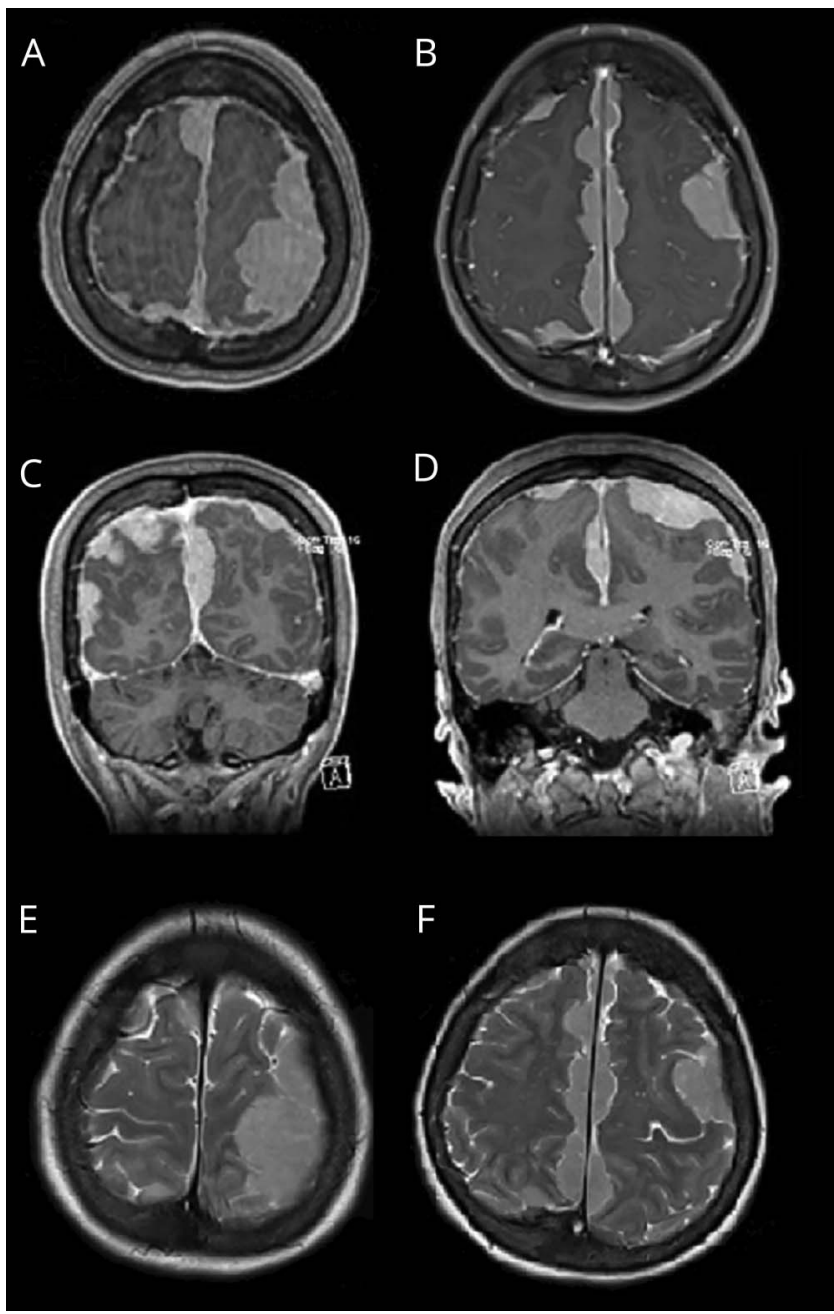

Axial (A, B) and coronal (C, D) T1-weighted MRI with contrast demonstrates multiple lobulated dural-based homogenous enhancing lesions. There is mild mass effect with no significant associated edema on T2-weighted images (E, F).

A 73-year-old woman with JAK-2-positive polycythemia vera, myelodysplastic/myeloproliferative overlap disorder, and biopsy-proven extramedullary hematopoiesis (EMH) involving pleura and paravertebral regions presented with 6 weeks of headaches and blurry vision. Examination showed

\section{Correspondence}

Dr. Zhou

lilyzhou@hsph.harvard.edu

\section{MORE ONLINE}

$\rightarrow$ Teaching slides

links.lww.com/WNL/B127

From the Department of Neurology, University of British Columbia, Vancouver, Canada.

Go to Neurology.org/N for full disclosures. Funding information and disclosures deemed relevant by the authors, if any, are provided at the end of the article. 
bilateral papilledema, preserved acuity, and mild right pyramidal weakness. MRI brain showed homogenously enhancing dural lesions with no associated edema (figure). She underwent external beam radiation (10 fractions, $200 \mathrm{cGy} /$ fraction) for symptomatic management.

EMH is seen in myeloproliferative neoplasms and hemoglobinopathies and more commonly involves liver, spleen, and lymph nodes. ${ }^{1}$ Intracranial EMH is rare and typically presents as dural ${ }^{1}$ or choroid plexus-based lesions ${ }^{2}$ with features of increased intracranial pressure.

\section{Study funding}

No targeted funding reported.

\section{Disclosure}

The authors report no disclosures relevant to the manuscript. Go to Neurology.org/N for full disclosures.

\section{Appendix Authors}

\begin{tabular}{lll}
\hline Name & Location & Contributions \\
\hline $\begin{array}{l}\text { Lily W. Zhou, } \\
\text { MD }\end{array}$ & $\begin{array}{l}\text { University of British } \\
\text { Columbia, Vancouver, } \\
\text { Canada }\end{array}$ & $\begin{array}{l}\text { Involved in first draft, } \\
\text { preparation of images, and } \\
\text { revisions }\end{array}$ \\
$\begin{array}{l}\text { Tychicus } \\
\text { Chen, MD, } \\
\text { FRCPC }\end{array}$ & $\begin{array}{l}\text { University of British } \\
\text { Columbia, Vancouver, }\end{array}$ & $\begin{array}{l}\text { Involved in first draft, } \\
\text { preparation of images, and } \\
\text { revision }\end{array}$ \\
\hline
\end{tabular}

\section{References}

1. Eskazan AE, Ar MC, Baslar Z. Intracranial extramedullary hematopoiesis in patients with thalassemia: a case report and review of the literature. Transfusion 2012;52: $1715-1720$

2. Tabesh H, Shekarchizadeh A, Mahzouni P, Mokhtari M, Abrishamkar S, Abbasi Fard $S$. An intracranial extramedullary hematopoiesis in a 34-year-old man with beta thalassemia: a case report. J Med Case Rep 2011;5:580. 


\section{Neurology}

\section{Teaching NeuroImages: Intracranial extramedullary hematopoiesis: Blood disorders on the mind}

Lily W. Zhou and Tychicus Chen

Neurology 2020;95;e606-e607 Published Online before print July 13, 2020

DOI 10.1212/WNL.0000000000009926

This information is current as of July 13, 2020

\section{Updated Information \&} Services

\section{References}

Subspecialty Collections

Permissions \& Licensing

Reprints including high resolution figures, can be found at: http://n.neurology.org/content/95/5/e606.full

This article cites 2 articles, 0 of which you can access for free at: http://n.neurology.org/content/95/5/e606.full\#ref-list-1

This article, along with others on similar topics, appears in the following collection(s):

\section{MRI}

http://n.neurology.org/cgi/collection/mri

Secondary headache disorders

http://n.neurology.org/cgi/collection/secondary_headache_disorders Visual loss

http://n.neurology.org/cgi/collection/visual_loss

Information about reproducing this article in parts (figures,tables) or in its entirety can be found online at:

http://www.neurology.org/about/about_the_journal\#permissions

Information about ordering reprints can be found online:

http://n.neurology.org/subscribers/advertise

Neurology ${ }^{\circledR}$ is the official journal of the American Academy of Neurology. Published continuously since 1951, it is now a weekly with 48 issues per year. Copyright @ 2020 American Academy of Neurology. All rights reserved. Print ISSN: 0028-3878. Online ISSN: 1526-632X.

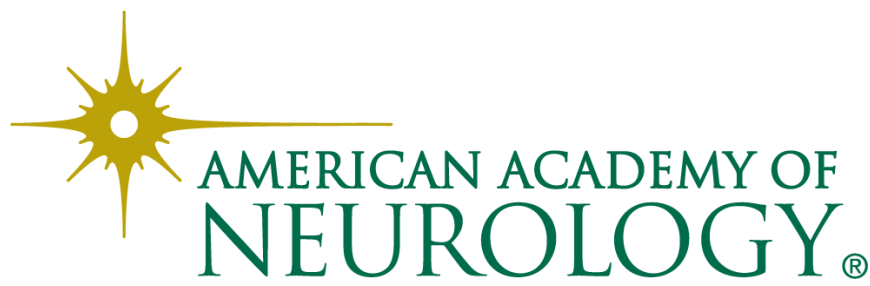

